\title{
THE IMPACT OF THE UNIFORM CONSUMER CREDIT CODE UPON THE MARKET FOR CONSUMER INSTALLMENT CREDIT
}

\author{
ROBERT P. SHAY*
}

\section{INTRODUCTION}

The market for consumer credit should become more competitive if the Uniform Consumer Credit Code (UCCC) is adopted by many states in its present form. The UCCC is a truly radical document in that it ignores the taboos and superstitions which, in the past, have dictated a legal form of consumer protection which has fostered monopolistic or oligopolistic markets with accompanying higher prices for credit. The UCCC's objective goes beyond bringing uniformity to legal regulations among the states-it intends to change the rules of the game within each state in order to achieve more competitive conditions and lower rates than are now available to borrowers. While to some extent the UCCC may enlarge the market for consumer borrowing by allowing competitive forces to operate more freely, its contribution in this direction will probably be minor. The UCCC preaches a greater belief in competition than its regulations suggest. While taking great strides toward allowing the market to determine who will be served, the UCCC's rate ceiling structure confines the total market fairly closely to customers now being served and segments most of the open-end portion of the market from the closed-end portion along traditional lines.

Analysis of the UCCC will be confined to those provisions which are expected to exert the strongest influence upon the market for consumer installment credit. These are $(a)$ rate ceilings upon finance charges and the doctrine of unconscionability, $(b)$ conditions of entry into competition for borrowers, $(c)$ disclosure of the terms of credit to borrowers, and (d) limitations upon creditors' remedies. I shall examine the probable effects of these changes upon the types of credit services offered consumers and upon the types of credit institutions which extend credit. However, there is the usual caveat which must be offered. I shall assume that the UCCC is adopted in most states without substantial change from the approved version. ${ }^{1}$ There is no assurance that the legislatures will buy the package in its present form. If they do not, all bets are off, and I shall try again at some future time to assess the consequences of the UCCC upon this market.

- B.S. I944, M.A. I946, Ph.D. x95I, University of Virginia. Professor of Banking and Finance, Graduate School of Business, Columbia University.

${ }^{1}$ On the approved text of the UCCC, see Foreword, in this symposium, p. 639 n.r. 


\section{Sale and Loan Credit: The Time-Price Doctrine}

The UCCC continues the practice of segregating regulations governing credit sales from those concerning cash loans despite the economic reality that there is little or no difference in the uses of the two forms of credit. As is obvious to the layman, the credit sale involves the granting of credit for the purchase of goods or services from a given (or multiple) seller(s), while loan credit involves the granting of credit in the form of generalized purchasing power (money) which may be used to purchase goods or services and repay debts. The economic effects of the two are virtually identical, as borrowers can manipulate their finances to purchase goods and services or consolidate debts.

If the legal distinction between the two had been ignored, the UCCC could have been shorter, simpler to use, and more accessible to businessmen and interested laymen. Further, a number of provisions have crept in along traditional, time-price doctrine lines, which continue segmentation of the market; i.e., a different rate ceiling for open-end credit sales than for open-end loan credit. All in all, the decision to maintain the legal fiction of the time-price doctrine in the UCCC has militated against its stated objectives.

\section{A. Closed-end Credit}

On closed-end transactions, UCCC rate ceilings on credit sales were set at the same level as those applied to cash loans. These levels-thirty-six per cent per annum on unpaid balances less than $\$ 300$, twenty-one per cent per annum on that part of the unpaid balance more than $\$ 300$ but not more than $\$ I, 000$, and fifteen per cent per annum on that part of the unpaid balance which is more than $\$ 1,000-$ determine when rates of charge become illegal under the UCCC. UCCC rate ceilings are high relative to most of the rate ceilings which exist among the effective small loan laws in forty-seven of the fifty states. ${ }^{2}$ The belief of the draftsmen of the UCCC was that rate ceilings should be set high to permit the free market to establish the price of credit for all but marginal borrowers. But rate ceilings will be lowered in a significant number of states if the UCCC is adopted. For example, on loans of \$roo, rate ceilings established by the UCCC are lower than those allowed in the small loan laws of fourteen states in early $1968 .^{3}$ As the credit size increases, the number of states with higher legal rate ceilings than the UCCC's declines to nine at $\$ 300$, seven at $\$ 600$, five at $\$ 800$, three at $\$ \mathrm{I}, 000$, and two up through $\$ 1,500$. On loans of \$roo, the UCCC rate ceiling is set at the median of the rate ceilings which existed in early I968. (See Table r.) From that point on, the UCCC rate ceilings are

\footnotetext{
${ }^{2}$ Arkansas, Delaware, and Tennessee are the three states which do not have small loan structures modeled closely on the Uniform Small Loan Law.

"Alaska, South Carolina, Oklahoma, Hawaii, Louisiana, Wyoming, Mississippi, Nevada, Florida, Indiana, Iowa, Rhode Island, South Dakota, and Utah.
} 
higher, reaching a peak at a credit size of $\$ 1,100$, with credit sizes in the range between $\$ 1,000$ and $\$ 1,300$ most favored.

It is apparently difficult to justify to legislators rates around or above thirty-six per cent per annum. For this reason, it appears to this observer that the notion of setting rate ceilings high relative to the expected going rate on a free market was not followed on credit sizes of $\$ 300$ or less. But on credit sizes of $\$ 1,000$ or more, rate ceilings on closed-end consumer credit transactions will be considerably higher than typical rates of charge on the market. While it should be noted that UCCC rate ceilings will be higher than existing median rate ceilings, the function of the UCCC rate ceiling is to decide when rates become unconscionable, not to set the going rate on the market, as is true of current rate ceilings.

\section{TABLE I}

Comparison of Median Yields of Selected Loan Sizes Under State Small Loan Law Rate Ceilings, Early rg68, with Proposed Rate Ceilings Under the UCCC

\begin{tabular}{|c|c|c|c|c|}
\hline Cash Advanced to Borrowers & $\begin{array}{c}\text { Number } \\
\text { of } \\
\text { State } \\
\text { Small Loan } \\
\text { Laws }\end{array}$ & $\begin{array}{c}\text { Median } \\
\text { Rate } \\
\text { Ceilings } \\
\text { Early } 1968 \\
\text { Cost }^{3}\end{array}$ & $\begin{array}{l}\text { Effective } \\
\text { Annual } \\
\text { Rate } \\
\text { Ceiling } \\
\text { UCCC }\end{array}$ & Difference \\
\hline 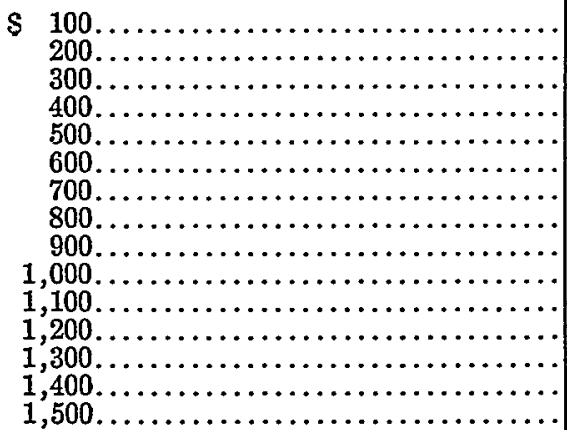 & $\begin{array}{l}47 \\
47 \\
47 \\
41 \\
41 \\
41 \\
35 \\
35 \\
31 \\
30^{\mathrm{b}} \\
18^{\mathrm{b}} \\
18^{\mathrm{b}} \\
18^{\mathrm{b}} \\
18^{\mathrm{b}} \\
18^{\mathrm{b}}\end{array}$ & $\begin{array}{l}36.00 \% \\
34.92 \\
32.88 \\
30.36 \\
28.80 \\
27.48 \\
26.52 \\
25.44 \\
24.72 \\
23.64 \\
22.20 \\
21.84 \\
21.72 \\
21.60 \\
21.36\end{array}$ & $\begin{array}{l}36.00 \% \\
36.00 \\
36.00 \\
34.80 \\
33.24 \\
31.80 \\
30.72 \\
29.76 \\
28.92 \\
28.20 \\
27.60 \\
27.00 \\
26.40 \\
25.80 \\
25.32\end{array}$ & $\begin{array}{l}1.08 \% \\
3.12 \\
4.44 \\
4.44 \\
4.32 \\
4.20 \\
4.32 \\
4.20 \\
4.66 \\
5.40 \\
5.16 \\
4.68 \\
4.20 \\
3.06\end{array}$ \\
\hline
\end{tabular}

(a) loans with 12 month maturity, January 1, 1968.

(b) dollar cost of loan computed by interpolation between states above and below median. Source: I am indebted to Helmuth Miller of Beneficial Finance Corporation for theso data.

Loan size ceilings are also abolished under the UCCC." The effect of this change will help all financial institutions who are limited to lending cash in amounts below a given size. To some extent the abolition of loan size limits will help lenders in those states with unrealistic loan size limits for all lenders. There may be some competitive effects among credit agencies which compete for the same borrowersclassified by their credit risk-such as commercial banks and credit unions. There will be considerably less competitive reallocation when loan limits are abolished

\footnotetext{
-UCCC $\$ 3.104$ defines a consumer loan as one in which, among other things, the principal does not exceed $\$ 25,000$. Thus loans exceeding $\$ 25,000$ are not directly regulated by the Code. See UCCC $\S 3.605$.
} 
for agencies which cater primarily to different credit risks, i.e., commercial banks and consumer finance companies. This is not to say that competition between banks and consumer finance companies will not develop for other reasons. But with rate disclosure, it is unlikely that high-rate lenders can draw borrowers away from lower-rate lenders when lending similar amounts unless they differentiate the services offered to overcome the difference in cost.

Whether rates actually charged for a given risk will rise or fall when rate ceilings become uniform and loan limits are abolished depends upon the working of two offsetting forces contained within the UCCC. First, there is the enlargement of the number and kinds of creditors allowed to extend credit in the high-rate, small credit size segment of the graduated rate ceiling on closed-end credit transactions. For the first time added competition from retailers, banks, and others will be brought into the market for the high-risk consumer loans previously made only by licensed lenders. With all segments of the consumer credit market free for the first time to charge rates up to the uniform rate ceilings, below-ceiling rates of charge will be encouraged by the removal of restraints on entry into the higher-risk portion of the market. The second and off-setting force is the combination of limitations placed upon creditors' remedies and upon agreements and practices ${ }^{5}$ which will increase both the risk and cost of extending credit. ${ }^{6}$ It is difficult to predict the net effect of these two factors upon marginal borrowers. But it seems likely that added competition will help to increase the number of borrowers to the extent that competition lowers rates for given credit risks. More borrowers could be accepted under the same rate ceiling as before unless the added risk through the loss of remedies was the dominant force determining which borrowers are marginal.

Although the rate ceilings are the same for credit sales and loan credit on closedend transactions, the competitive impact of uniform rate ceilings will not necessarily be the same, particularly in the case of marginal borrowers. At the present time, in the many states with rate ceilings applicable to the financing of credit sales, retailers, commercial banks, and others will be given access to a higher-rate, higher-risk market which was previously only legally open to licensed lenders. In addition to having the right to charge equivalent rates, retailers will remain free to absorb portions of the finance charges required to make even riskier loans than those made by lenders by increasing their cash prices, especially when their customers are mainly credit-using, high-risk borrowers. The portions of the UCCC rate ceilings which are low relative to those in states which have higher small loan rate ceilings are precisely those small credit sizes which accompany the sale of low quality goods at inflated prices to the credit-using poor. ${ }^{7}$ In these instances not only will retailers be given a competitive position which will allow them to finance higher-risk bor-

\footnotetext{
${ }^{\circ}$ UCCC art. 5 , pt. I; art. 2, pts. 4 , 5; art. 3 , pt. 4 -

'UCCC $\$ 2.201$, Comment.

${ }^{7}$ See D. Caplovitz, The Poor Pay More i6-20 (paper ed. I967).
} 
rowers than lenders, there will be an opportunity for some retailers to lower the markup on prices of goods sold on credit to customers when they are allowed, for the first time, to extend credit at rates equivalent to those charged by small-loan lenders.

Yet in those states without legal rate ceilings on credit sales, there will be little change in the competitive atmosphere unless retailers catering to marginal borrowers were actually charging rates higher than those permitted by the UCCC. Since such rates would attract attention and thereby lead to regulation, it is likely that any such specialized retailers are already inflating their cash prices rather than the finance charge when they cater to the credit-using poor.

It will be interesting to see whether the typical retailer will move into the highrisk segment of the consumer credit market when and if the UCCC rate ceilings are adopted. For many years before retail installment sales acts began to be passed in the mid-1930s, retailers were free to charge whatever they pleased, and, for the most part, they did not undertake the financing of high risks. Rates were high because costs were high, as they are today, but the procuring of extra gains from cultivating the poorer risks and charging accordingly was not considered an appropriate function for retailers. Today, or, even more important, tomorrow, the situation may well be different, as retailers become more diversified in their interests and activities. Already, manufacturers have sensed that merchandising credit to purchasers of their products is an essential adjunct to production and distribution. The giant retailers and mail-order houses now realize it as well. While the typical large retailers would not be expected to adjust their cash prices as freely to subsidize credit as a seller catering solely to marginal credit risks, the opportunity to enter the high-risk market on the same basis as cash lenders could make many retailers effective competitors using the highly sophisticated credit scoring systems made possible by computers today.

To conclude, the UCCC's uniform rate ceiling on closed-end credit will allow both lenders and sellers who were previously locked into the lower-rate end of the market by legal rate ceilings to compete with other lenders and sellers for higherrisk borrowers. There may be a reverse movement if the cash lenders previously serving higher risks feel forced to compete for lower-risk borrowers when they lose their monopoly position in the high-rate portion of the market. But because there are many more states whose current rate ceilings are below those set by the UCCC than the converse, there will be a net expansion in the size of the market that may leave room for all without creating cut-throat rate competition. Thus, the shortrun competitive effects of the adoption of the UCCC should mean that higher-risk borrowers could be served more uniformly throughout the states. The longer-run effects could come when competition forces credit agencies to price credit according to the degree of credit risks in the credit applicant's statement, thereby lessening the degree of specialization among types of financial institutions in catering to certain credit risk groups and charging a single price. When this phenomenon occurs, one 
will find competition working to bring some borrowers lower rates of charge while other borrowers will pay more. Presumably, on average, the increased competition should bring lower rates for given risks.

\section{B. Open-end credit}

Revolving charge accounts and revolving loan arrangements have been a growing but still relatively minor component of the consumer installment credit market. With the exception of charges for "supervised" loans, the framers of the UCCC chose to segment this portion of the market from the closed-end credit sector by establishing lower rate ceilings. Further, higher rate ceilings were set for open-end sales credit than for open-end loan credit. ${ }^{9}$ While the justification of the time-price doctrine has always escaped this economist's sense of logic, that distinction at least differentiated the sale of goods on credit from the loan of money. The distinction between open-end sale credit, called revolving charge accounts, and open-end loan credit, called revolving loan credit, is that the credit contract is made with a seller in the first instance and with a lender in the second. Both may issue a credit card which can be used to purchase goods, but the seller in the first instance is given a higher rate ceiling than the second. This makes no sense, if we disregard the mandate of power politics.

The significance, first of all, of a lower rate ceiling for open-end credit transactions than for closed-end transactions is that higher-risk borrowers will only be able to avail themselves of the conveniences inherent in revolving credit arrangements when supervised lenders develop such plans. Such arrangements are not common today. And the existence of a lower rate ceiling for competitors which have developed such plans for the better credit risks will insure that they will not become common in the high-risk area tomorrow. Who is being protected by any such limitation? When closed-end transactions are already being refinanced widely before they fall due, is the marginal borrower being protected from himself when he is denied the possibility of a kind of credit which some creditor may some day think he could handle? Or is the lower rate ceiling a device to perpetuate the system of closed-end credit transactions? Why not allow competition among all creditors to decide when the open-end system can be made available to high-risk borrowers?

The impact of a higher rate ceiling upon revolving charge accounts than upon revolving loan accounts cannot be anything other than a hoped-for subsidy for the retailer because of his traditional role as originator of the revolving credit account.

\footnotetext{
${ }^{8}$ See UCCC, art. 3, pt. 5. A "supervised loan" is defined in UCCC $\$ 3.5$ or, and the finance charges are set out in $\$ 3.508$. In general, a "supervised lender" is a lender licensed by the state and therefore permitted to make loans at higher rates.

${ }^{\circ}$ On revolving charge accounts the charge may not exceed $2 \%$ a month on balances of $\$ 500$ or less, and $I \frac{1}{2} \%$ on that part of the balance over $\$ 500$. UCCC $\$ 2.20 \mathrm{r}$. On revolving loan accounts the charge may not exceed $18 \%$ per annum if based on a monthly charge of $I \frac{1}{2} \%$ on the balance. UCCC $\$ 3.201$. For supervised lenders, higher ceilings on closed-end transactions are allowed. UCCC $\S 3.508$.
} 
If there is some justification for allowing the seller the higher rate ceiling because he has first access in most instances to the borrower, it is not apparent to me. This is another anomalous interference with free competition in a Code which professes its virtues. ${ }^{10}$

\section{EASE OF ENTRY}

Entry into consumer credit markets has up to now been limited in three ways:

a. limitations upon the number and geographical location of offices which may extend loans. Such limitations apply only indirectly to credit originated by dealers and sold to sales finance companies and commercial banks.

b. regulations which prohibit the extension of types of consumer credit by certain financial institutions, i.e., mutual savings banks and savings and loan associations in most states.

c. different rate ceilings which now apply to the different arrangements by which consumers may finance the purchase of goods and services or consolidate their debts.

The limitations placed upon the number of offices and their geographical location apply mainly to commercial banks and consumer finance companies, among the major credit agencies operating on the consumer credit market. Such restrictions limit direct loans which, for the most part, require the presence of the borrower on the premises of the lender. The purchase of paper originated by dealers and sold to credit agencies is less affected by the limitations placed upon the location of offices.

At first glance it would appear that commercial banks have been most affected by state statutory limitations on branching and "convenience and need" standards for any given office location. But this is not necessarily the case since banks are not solely restricted to the direct loan portion of the consumer credit market. When limited to single offices or limited branching status, they have shifted their emphasis to dealer paper, and in some states allowing statewide branching, like California, they have found that the purchase of automobile installment credit contracts from dealers was preferable to aggressive solicitation of direct automobile loan customers.

Consumer finance companies are most affected by limitations on entry in states which do not allow them to do a dual business. In five of the six states which limit entry most strongly under the small loan laws, prior permission of the supervisory authorities must be obtained in order to do a dual business. ${ }^{11}$

The UCCC, as noted above, substantially lowers the restraints upon entry by

\footnotetext{
${ }^{10}$ See UCCC, Prefatory Note, at xv.

${ }^{11}$ For a listing of the relative severity of administration among 17 states with convenience and advantage clauses, see The Consumer Finance Industry: Its Costs and Regulation ir3 (J. Chapman \& R. Shay ed. I967).
} 

borrowers seek out higher cost sources to obtain more credit, they again find themselves rationed, as lenders and sellers determine that their incomes will not support the monthly payments required to satisfy their wants. In this situation disclosure of rates of charge will not change many borrowing decisions. Only those relatively few consumer borrowers, whose borrowing needs are less than their credit standing will allow, will be rate sensitive, and for them disclosure may make a difference.

On the other hand, the constraints placed by lenders upon borrowers can be expected to ease when adoption of the UCCC brings increased competition to the market for consumer installment credit. There are many states where the needs of borrowers are not met because the law created a monopoly position for regulated lenders and then circumscribed their position so that they could only offer competitive alternatives at low rates of charge. In New York, for example, a borrower can obtain loans to consolidate debts from commercial banks at a ceiling rate of twelve per cent per annum up to $\$ 5,000$. The largest small loan which a borrower can obtain from a consumer finance company under New York's small loan law is $\$ 800$. If he cannot qualify for a loan, say, of $\$ 1,600$ from a bank, he may try to make two $\$ 800$ loans from adjacent consumer finance company offices, which is legal under the law. There is no reason for the second loan office to turn the borrower down in his application even when he knows that the borrower has just obtained the first $\$ 800$ loan from the neighboring office because the risk is justifiable at the nineteen per cent annual rate of charge. But under the UCCC, the borrower may receive a rate of charge between twelve and nineteen per cent if competition works because costs are lower for extending, servicing, and collecting one loan of $\$ 1,600$ than two loans of $\$ 800$. And it will be most surprising if some class of lender does not discover that he can tap a market not currently being served by offering debt consolidation loans to borrowers who can qualify for credit at similar rates, heretofore not available. And, more than likely, existing lenders who feel the loss of business may re-price their loans so that they offer loans at different rates where there are different credit risks to serve. The end result may be that some creditors will continue to specialize in the kinds of business they do best while others may diversify into a number of types of consumer installment credit.

The competitive environment brought about by the Consumer Credit Protection Act will provide enough information so that borrowers will be better able to compare rates of charge and dollar costs among competing credit alternatives. Credit advertising can become a device that a creditor seeking to build a new market for his services will find advantageous. If he advertises, then he must comply with the CCPA by including in the advertisement ( $\mathrm{I}$ ) the cash price, or the amount of the loan as applicable, (2) the downpayment, if any, (3) the number, amount, and due dates or period of payments scheduled to repay the indebtedness if the credit is extended, and (4) the rate of the finance charge expressed as an annual percentage 
rate. ${ }^{14}$ The very fact of disclosure and advertising of the terms of the credit contract will place the borrower in a much better position to assess his alternatives than he has ever been before. I foresee an initial period when borrowing habits do not change much, simply because alternatives are the same and creditors will take time to discover borrowers' preferences. But I fully expect that, as time passes, creditors will seek out the profit opportunities made possible by the relaxation of legal barriers to protected markets and that, then, the disclosure provisions will accentuate the speed with which such attempts meet with success. For a borrower to respond to a new credit alternative, he must be able to compare credit costs, as he can when the uniform disclosure system is utilized by all creditors. Experience in Massachusetts with disclosure has suggested that it will take time for borrowers to begin to shop for credit. ${ }^{15}$ Further, it will not be until additional alternatives appear that there will be appreciable gains to them from shopping. Borrowers know, for example, that certain kinds of credit are more costly than others and that certain types of credit institutions charge more than others for credit. ${ }^{16}$ In short, borrowers have sorted themselves out pretty well among the limited alternatives now available to them.

\section{IV}

\section{Limtations Upon Creditors' Remedies and Defenses}

The removal of the defenses of the purchaser of a credit contract from the buyer's claims against the seller presents a radical change from present circumstances. ${ }^{17}$ This provision means that anyone to whom the rights to payment are assigned by the seller must consider that, if the seller does not fulfill his legal obligations under the credit sale, the financing agency will be subject to the buyer's defenses and be legally unable to collect the indebtedness; previously such defenses have been ineffectual against one who "innocently" purchased a negotiable note from the credit seller. The financing agency must share in the responsibility along with the seller for the fulfillment of the terms of the sale if he wishes to collect the indebtedness in full. The result will be to make financing agencies which purchase paper from dealers more careful about the paper that they purchase, with particular emphasis upon the dealer's past performance in his dealings with his customers.

It is clear that this restriction will fall primarily upon the sales finance companies and commercial banking groups which, together, hold the bulk of installment credit outstanding. Yet a fairly large proportion of the sales finance group are sub-

\footnotetext{
14 CCPA $\$$ I44. These requirements are only for closed-end transactions. The advertising disclosure requirements for open-end credit are set forth in CCPA $\$$ I43.

${ }^{16}$ See Federal Reserve Bank of Boston, New England Business Review 2-8 (Sept. I968).

${ }^{10}$ For some tests of consumer knowledge, see F. Juster \& R. Shay, Constumer Sensitrvity to Finance Rates 73, 74 (Nat'l Bureau of Economic Research I964).

${ }^{27}$ UCCC $\$ 2.403$ provides that the seller cannot take "a negotiable instrument other than a check as evidence of the obligation of the buyer or lessee." See also UCCC $\$ 2.404$, alternatives A and B.
} 
sidiaries which hold paper originated by dealers either franchised or owned by parent companies, which, in turn, can control the seller's policies. ${ }^{18}$ The commercial banking group and the independent sales finance companies have no such recourse and will have to guard against fraudulent practices by marginal sellers. While such vigilance by financing agencies helps to improve performance of sellers, it will add to the costs of purchasing and servicing installment paper originated by dealers. Among commercial banks, the effect of relaxing the defenses of holders in due course of installment paper will be to increase the incentive of banks to lend directly to borrowers and decrease their incentive to purchase dealer paper. For the independent sales finance company, there may be further diversification away from purchased paper. Thus, there will be some curtailment in the availability of credit and some increase in cost resulting from the added consumer protection.

The limitations upon creditors' remedies in the UCCC comprise a wide variety of similar provisions from existing state laws. There can be no assignment of earnings in the UCCC, although voluntary authorization to deduct payments is permitted if it is revocable. ${ }^{10}$ Confessions of judgment are prohibited. ${ }^{20}$ Deficiency judgments cannot be obtained after repossession or surrender of the goods purchased when their cash price is $\$ \mathrm{r}, 000$ or less. ${ }^{21}$ There can be no garnishment of wages prior to an entry of judgment in an action against the debtor, ${ }^{22}$ and limitations on garnishment are provided. ${ }^{23}$

The net effect of these provisions is not likely to be as substantial as their listing implies. Most states have enacted some of these limitations on creditors' remedies, but few have combined them as effectively. The consumer, especially the higher-risk borrower, will pay a price for his protection. The added risk of being unable to collect will make credit more costly. And, unless the legal rate ceiling is high enough to allow the creditor his compensation for the risk, the credit will not be extended through legal sources.

The limitations upon creditors' remedies affect both sales credit and loan credit, so that no major shift between the two, as was suggested might result from the strengthening of defenses against holders in due course, can be expected to occur as a result of these changes. The major effect expected, however, will be in the higher cost of obtaining credit, except for those borrowers of small amounts who may not have sufficient leeway under the UCCC's rate ceilings to still qualify for credit. Although the Code states that its proposed rate ceilings are "intimately related to other parts of the act which provide for limitations on agreements and

\footnotetext{
${ }^{18}$ While it is unlawful under antitrust laws for manufacturers to restrict their dealers to offering to borrowers only the financing services of wholly owned finance subsidiaries, presumably manufacturcrs could exert pressure on their dealers to fulfill the terms of the sale or lose their franchise.

${ }^{10} \mathrm{UCCC} \S 2.410$.

${ }^{20} \mathrm{UCCC} \S 2.415$.

${ }^{21}$ UCCC $\$ 5.103$.

${ }^{22}$ UCCC \$ 5.104.

${ }^{23}$ UCCC \$ 5.105.
} 
practices (Article 2, Parts 4 and 5; Article 3, Part 4) and for limitations on creditors ${ }^{*}$ remedies (Article 5, Part I), ${ }^{, 24}$ it is my judgment that although it recognizes that on balance, the costs of credit will be higher as a result of these provisions, the UCCC does not make any real allowance for such increases in rate ceilings among borrowers. of small amounts.

\section{Conclusions}

In reviewing the potential impact of the UCCC upon the consumer installment credit market, conflicting forces have been noted, some contributing to a widening of the market through lower, more competitive charges and others narrowing the market by removing some creditors' remedies available under current laws. On balance, it appears that the competitive forces unleashed by removing much of the current market segmentation will be dominant. Thus, the expected net result of the enactment of the Code involves the combination of lower rates of charge for a given credit risk and wider availability of credit to borrowers generally.

The UCCC should affect portions of the consumer installment credit market differently. The automobile financing market, comprising about two-fifths of total installment credit outstanding, will be least affected since it is already highly competitive. There may be some extension of the market involving assumptions of the higher risk consistent with higher rate ceilings, which would imply creditors would accept borrowers whose credit standing and collateral previously were not acceptable. Also, there may be competitive inroads by direct automobile lending upon the volume of credit financed indirectly because of the changed status of the holder in due course. Over the long run, there may be further shifts of automobile credit to lower-rate institutions as borrowers find their lowest-cost alternatives through the disclosure provisions of the CCPA and the UCCC. But the automobile financing market should not be expected to show marked changes, since entry is already relatively free, and existing rates of charge are well below legal rate ceilings in most heavily populated areas.

The potential impact of the UCCC upon the market for other consumer durable goods financing is more complex to determine. The bulk of outstanding durable goods credit is financed by retailers who either hold their own paper or sell it to. commercial banks or sales finance companies. Further, only slightly more than half of the states have enacted legal rate ceilings on this form of retail sales financing, and they are substantially lower than those envisioned in the UCCC. Rates of charge appear to be quite standard between eighteen and twenty-four per cent per annum, although no formal study supports this observation. Nor is there any evidence that rates are very different in states with no legal rate ceiling. Competition, or the lack of it, in this market has been largely on a nonprice basis but most recently has. emerged in the form of a competing type of credit instrument, the all-purpose credit

${ }^{24}$ UCCC $\$ 2.201$, Comment. 
card. Such cards, and related plans, have emerged at costs which are comparable to those under existing revolving credit arrangements.

The UCCC has given retailers some financial protection against further invasion of their revolving charge accounts by allowing them a premium in the rate ceiling above that permitted on revolving loan accounts. But the UCCC has closed off the possibility that lower-risk, open-end revolving plans could gradually be extended to higher risks by establishing special (lower) rate ceilings for unsupervised lenders and sellers. Only supervised lenders can avail themselves of the opportunity to extend open-end loans under the highest allowable rate ceilings in the UCCC. Such preferential treatment risks establishing the kind of monopoly position for future highcost, open-end financing which the UCCC is attempting to remove in closed-end financing.

The third major component of installment credit, personal loans, will be the most affected by enactment of the UCCC. Commercial banks, consumer finance companies, and credit unions are the institutions which will be most affected. Commercial banks, first of all, will have a greater opportunity to make loans at higher rates to borrowers whose credit risk is comparable to those accepted when they purchase dealer paper. Further, banks and credit unions will be free to tap the market for borrowers previously rejected at rates higher than those charged under their current rate ceilings but lower than those charged by consumer finance companies. By expanding their operations in both areas, commercial banks could gain substantially in the personal loan market. Both banks and credit unions, if they move to accept borrowers in the higher risk categories, could place strong pressure upon rates of charge (and dealers' finance charge participation) in retail sales financing while gaining some customers from consumer finance companies. Besides expanding their operations in states which obtain higher rate and loan ceilings under the UCCC, consumer finance companies may wish to join the competition for borrowers at rates substantially below the UCCC rate ceilings. But their experience and special competence has always been in the handling of higher risks, and it seems logical that they would continue to be dominant in this segment of the market under highly competitive conditions.

If the UCCC is enacted in many states in anything like its present form, competition will be the name of the game, even if still circumscribed to some extent. For those who have preached competition over the years, it is time to rally to the cause and support the Code. There is much to be gained by efficient lenders, sellers, and alert borrowers. 